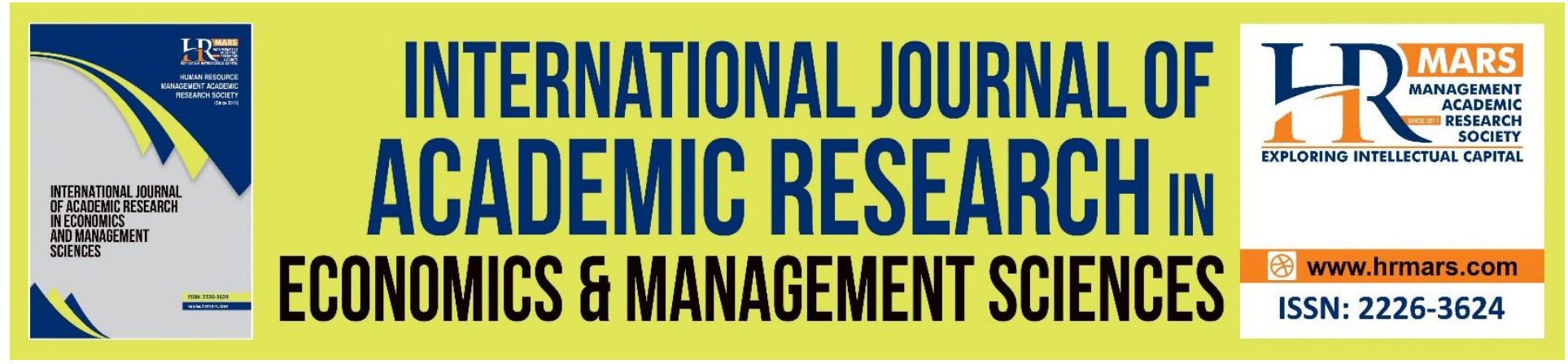

\title{
COVID-19 and Public Administration: Global Economic Management
}

Mahboob Ullah, Enayatullah Habibi, Hamdullah Nezami

To Link this Article: http://dx.doi.org/10.6007/IJAREMS/v10-i1/9183

DOI:10.6007/IJAREMS/v10-i1/9183

Received: 02 January 2021, Revised: 28 January 2021, Accepted: 23 February 2021

Published Online: 24 March 2021

In-Text Citation: (Ullah et al., 2021)

To Cite this Article: Ullah, M., Habibi, E., \& Nezami, H. (2021). COVID-19 and Public Administration: Global Economic Management. International Journal of Academic Research in Economics and Managment and Sciences, 10(1), 34-45.

Copyright: (C) 2021 The Author(s)

Published by Human Resource Management Academic Research Society (www.hrmars.com)

This article is published under the Creative Commons Attribution (CC BY 4.0) license. Anyone may reproduce, distribute, translate and create derivative works of this article (for both commercial and non-commercial purposes), subject to full attribution to the original publication and authors. The full terms of this license may be seen

at: http://creativecommons.org/licences/by/4.0/legalcode

Vol. 10, No. 1, 2021, Pg. 34 - 45

http://hrmars.com/index.php/pages/detail/IJAREMS

JOURNAL HOMEPAGE

Full Terms \& Conditions of access and use can be found at http://hrmars.com/index.php/pages/detail/publication-ethics 


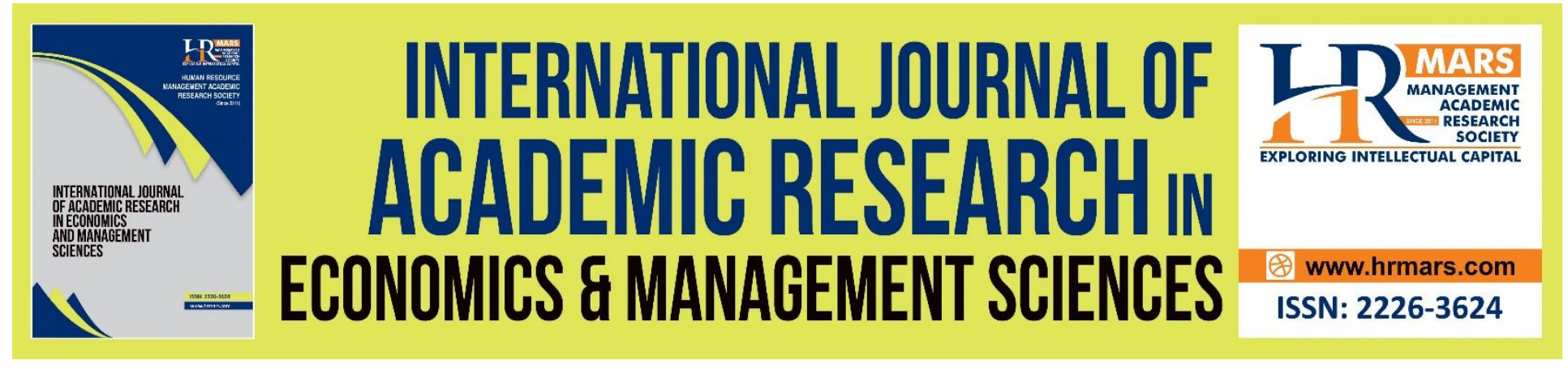

\title{
COVID-19 and Public Administration: Global Economic Management
}

\author{
Mahboob Ullah \\ Associate Professor, Department of Management Sciences, Khurasan University, \\ Nangarhar, Afghanistan \\ Enayatullah Habibi \\ Assistant Professor, Head of Business Administration Department, Economics Faculty \\ Nangarhar University, Afghanistan \\ Hamdullah Nezami \\ Associate professor, Head of National Economics Department, Economics Faculty \\ Nangarhar University, Afghanistan \\ Email: mahboobmails@gmail.com
}

\begin{abstract}
The entire world community, starting in mid-December 2019, has come under the enormous influence of the World Coronavirus Epidemic, called COVID-19. The pandemic caused by this virus has already caused thousands of casualties around the world, imposed significant restrictions on the socio-cultural life of the population and radically changed the trends of the global economy. The main purpose of this work is to determine the status and trends of the impact of the recent pandemic situation, which is associated with the emergence of COVID-19. In the process of writing the article, the authors determined the impact of the pandemic situation in the world on the development of the public administration system in the context of economic management. It was found that the following can be considered the basic consequences of the pandemic situation in the world: decline in stock exchange indices; a significant drop in oil prices and a slowdown in the development of the precious metals market; reduction or partial termination of production in the context of economic management. The above factors indicate that today there is a real need for the implementation of anti- crisis and stabilizing measures on the part of government bodies.
\end{abstract} Key words: COVID-19, Public Administration, Global Economic Management 


\section{Introduction}

\section{Background}

Public administration is a type of activity of the state, exercising managerial organizing influence by using the powers of the executive power through organizing the execution of laws, exercising administrative functions for the purpose of comprehensive socio-economic and cultural development of the state, its individual territories, as well as ensuring the implementation of state policy in the relevant areas of public life, creating conditions for citizens to exercise their rights and freedoms (Khan, Ullah, Usman, Malik, Khan, 2020). Public administration is a component of political administration, that is, the process of implementing state executive power as a means of functioning of any social community. In some countries (for example, in Croatia) a separate ministry is in charge of these state activities.

The following features of public administration are distinguished, and its essence is revealed: 1. Public administration is always a certain organizing activity, as a result of which specific, managerial relations arise. 2. A prerequisite for their emergence is the presence of a subject, endowed with powers for the implementation of managerial functions. 3. For the emergence of managerial relations, in addition to the subject, the object (objects) must also participate in them, on the activity of which the subject's control action is directed. 4 . The nature of the relations that arise between them is always imperious, and in the conditions of state administration - state-imperious, and these powers are always endowed with one party - the subject of management, and the object of management is only the executor of instructions and directives, come from the subject. 5. Organizing activity of a state-power character consists in the implementation and management in accordance with the requirements of $X$, that is, subordinate, based on current legislation. 6. The managerial impact arising during this organizing activity and the establishment of managerial relations can have a different character in its parameters: it is state regulation, and centralized management, and operational management. 7. State administration, functioning in the legal field of the current legislation, in case of its violation, entails legal responsibility.

It is possible to separate the following characteristic features of public administration in the context of economic management: 1 ) executive and administrative character; 2) legality; 3 ) scale and versatility; 4) hierarchy; 5) organizing nature. The executive and administrative character means that public administration is made up of two interrelated aspects: executive and administrative activities. Bodies exercising public administration are executive structures, and is reflected in their name (executive bodies). Their main purpose is to organize the implementation of legislative acts adopted by parliament and acts of the head of state. At the same time, the implementation of this function is impossible without the implementation of certain administrative actions. Administrative activity is implemented: firstly, due to the publication of generally binding regulatory legal acts (decrees, regulations, orders, orders, etc.); secondly, in organizing the fulfillment of these instructions; thirdly, in monitoring their implementation (Kryshtanovych et al., 2020; Ullah, Khan, Usman, 2020). The subordinate nature of public administration is understood as the implementation of executive and administrative activities on the basis of legal norms, the main place among which belongs to the Constitution, laws, acts of the head of state. It is they who create the legal basis for the implementation of public administration and determine the boundaries of its executive direction, the main means of achieving goals (Prystupa et al., 2020). The scale of public administration means that this 
public administration activity is the most extensive in the state. It covers all of its territory and a huge number of management facilities. The sphere of his direct jurisdiction includes legal, informational, economic, financial, technical, organizational, human and other resources available to the state. The universality of public administration is expressed through the activity of executive authorities, which is continuous, that is, it is impossible without daily and constant managerial influence on public relations, covering all spheres of public life without exception and is carried out at all levels of government - from the center to regions and specific territories. The hierarchy lies in the fact that the system of executive authorities is built on the basis of clear subordination and subordination of lower bodies to higher ones. The organizing nature of public administration is expressed through its controlling influence aimed at organizing joint work of members of society, social groups, organizations in order to ensure the life of the state and ensure the well-being of its citizens using for this means of production, natural resources, material and other values.

The World Health Organization officially declared coronavirus a pandemic in early March 2020. Although the outbreak began in mid-December 2019 in Wuhan, central China. During this time, the pandemic has significantly affected the trends of the world economy, leaving no country aside. First of all, this is due to strict quarantine measures imposed by the governments of many countries: the closure of shopping and entertainment centers, a ban on all public events, restrictions on movement both within the country and when crossing its borders, reducing production (due to setting limits for the simultaneous stay of employees in one room), etc. Some companies have transferred their employees to work at home, while others are forced to send their employees on vacation. At the same time, there are cases of abuse and violation by some employers of the terms of the employment contract, which require employees to write applications for dismissal of their own volition or to take leave at their own expense. All this has a negative impact on the welfare of the population, their financial situation and in the near future will reduce their demand for a number of goods and services. World-renowned companies such as Apple, Toyota, Starbucks, McDonald's and Volkswagen have suspended production or sales in China as a result of the spread of coronavirus disease. The world's production chains, from electronics and cars to chicken, are under threat. The world's leading airlines have temporarily canceled flights to China. In his comment on the electronic portal "Word and Business", economic expert Barberis (2012) noted that a number of leading institutions as of early March 2020 noted a decrease in economic growth from an average of $2.5 \%$ to $0.6 \%$. According to the expert, in 2020 the global economic situation will be close to recession: many economies will face a reduction in exports, imports, GDP, attracting investment, including in the real estate market, the production sector will deteriorate significantly.

Analysts predict that the damage to the world economy due to the coronavirus pandemic in the worst case scenario could reach $\$ 2.7$ trillion. However, it is impossible to accurately calculate the expected losses, because every day more and more countries join the list of countries affected by coronavirus. 


\section{Literature Review}

In the context of reforming public administration in the world, the introduction of the latest management practices into the general system of the state, which would be able to withstand modern challenges, risks and threats, is of particular importance (Rowe \& Frewer, 2004).

Public administration, as it was said in the works of McSwite (2005) and Fredrickson (2007), has recently been the subject of study by many scientists and specialists. The introduction of new concepts in science reflects the realities of today. With the development of statehood and the complication of the legal system, a tendency towards an increase in the role of public principles in public life is increasingly manifested. In many countries, there is a general pattern of recognition of the national significance of the public sphere and the role of the state in social progress. A person appears in the center of the mind as a citizen of a developed democratic state.

Howlett, Mukherjee, Woo (2015) and Bovaird, Loeffler (2018) believe that the public administration system is the organizational structure of the state apparatus, the staff of which implements a set of necessary functions, using a set of appropriate forms, methods and procedures, as well as direct and feedback links between the state and society.

Such scientists as Bryson, Quick, Slotterback, Crosby (2013); Hafer, Ran (2016) argue that public administration, its concept and role change over time, and determine its properties:

- $\quad$ - covers all three spheres of power: executive, legislative and judicial and their relationships;

- - plays an important role in the formation of public policy and thus is a component of the political process;

- - significantly different from private administration; - interacts with numerous private groups and individuals in the provision of services to the community.

Talbot (2018); Ongaro, Van Thiel (2018) have noted that the subject of public administration is the process of achieving national goals and interests by organizing the activities of public entities, including legislative, executive and judicial bodies and local self- government bodies. In the context of the change in the concept of "rule of law" and the gradual disappearance of rigid boundaries between the state and society, public administration is increasingly responsible for the task of formalizing public and state processes

The fundamental scientific works of Piattoni (2009); Rowe, Frewer (2004); Drechsler (2013); Cooper, Bryer, Meek (2006) are devoted to the formation of the theoretical foundations of the study of the main factors of influence on public administration. Borras (2011), Adejare, Oluwafemi (2014) and many other scientists were involved in the study of the main factors of influence on public administration, including scientists as Bovaird, T. (2007) and Loeffler (2018) who studied the influence to a greater extent of social factors of influence both on the public administration system and on the entire economy of a particular country.

Capano, Howlett (2020); Porter, Hook (2020) in their works studied modern factors of influence on the system of public administration. The topic of epidemic danger and its further development could not be omitted in this work. In the opinion of these authors, in 2020 it was this factor of influence that became decisive in the implementation of the public administration system and it is from this factor that the government and special government structures need to build on when building an anti-crisis strategy for public administration. The impact of today's epidemic has also been studied and analyzed in the works of scientists such as Spanou (2020); Dunlop, Ongaro, Baker (2020). 
Despite the existence of works devoted to the direct impact of the current epidemic situation on the public administration system, according to the authors, this topic has not yet been fully disclosed and requires a more detailed analysis of this impact.

\section{Research Model}

Public administration is a practical activity in the context of economic management. Scientists pay attention to the key role of this activity in society and the state. It ensures self-preservation, existence and development of society. Let us emphasize that the success of the state and the country largely depends on the effectiveness of the system of public administration and local self-government. State administration is a highly complex creative type of professional activity of civil servants and local government officials. Therefore, the third meaning of public administration is that it is a developed educational industry that provides professional training, has an urgent need for a systemic phenomenon of public administration knowledge, for its educational and methodological support.

In order to better assess the impact of Covid19 on the system of public administration of the countries of the world, we analyzed the corresponding theoretical base and made the appropriate conclusions. Europe may face a serious economic shock that echoes the 2008 global financial crisis, and world leaders will not take urgent action against the coronavirus outbreak in the context of economic management.

According to him, US financial analysts (Porter, Hook, 2020), China's influence on the US will be twofold - as a consumer of American goods and as a global producer. Chinese consumption of foreign goods will decline, which will affect some companies more than others (car sales fell $92 \%$ in February 2020). The effect of disruptions in Chinese industry will be more tangible. China reported its worst-ever manufacturing performance in February 2020, lower than during the 2008 global economic crisis.

America imports from China goods with a total value of about $\$ 350$ billion, including components for a large number of other products that are already produced by US companies.

\section{According to the Foregoing, we can make the following Generalizations}

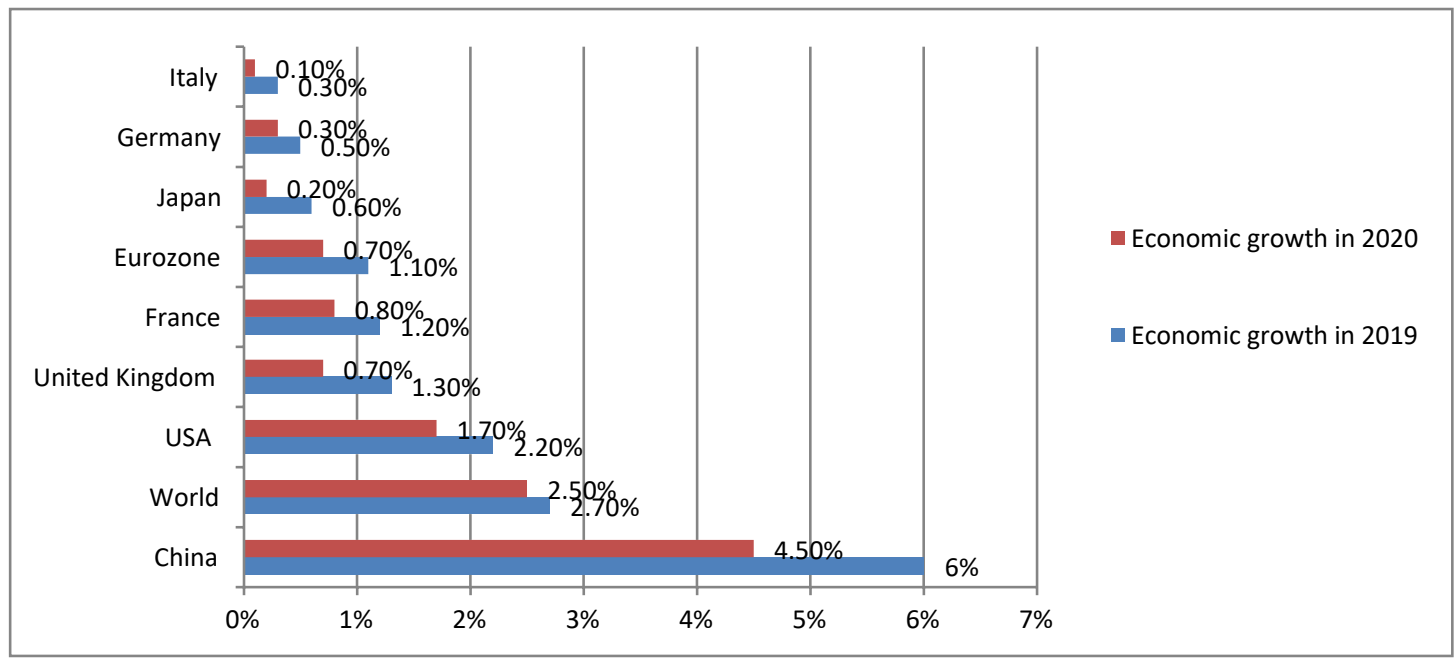

Figure 1. Economic growth of the world in 2019-2020 
Source: development by authors

1) The decline in economic growth rates of the leading countries of the world (Fig. 1), in particular, in the first quarter of 2020, China's economic growth decreased to $4.5 \%$ compared to $6 \%$ in the fourth quarter of 2019 ;

2) the fall in the index of stock exchanges in America, Europe and the countries of the AsiaPacific region;

3) a significant decline in oil prices (Fig. 2), which is due to a decrease in demand for oil, incl. from China, which is one of its main importers, by 435,000 barrels in the first quarter of 2020, which is equivalent to more than $\$ 2$ billion; slowdown in the development of the metals market: in mid-January 2020, it "sank" by $7.1 \%$. Copper index fell by $10.4 \%$, nickel - by $8.7 \%$, tin - by $8.2 \%$, zinc - by $7.3 \%$, lead - by $4.6 \%$, aluminum - by 3.5\%.At the end of February 2020 , the FTSE All World global stock index lost about $13 \%$, or what it had accumulated over the previous six months. This wiped out nearly $\$ 6$ trillion in market value for the index - a record loss in its history. The key US stock index fell $9 \%$ over the week. At the same time, the value of assets belonging to the "safe haven" class grew, in particular US Treasury bonds;

4) lack of products and components from China, which are the basis for the production of integral objects of foreign companies (Apple, Jaguar, Toyota, olkswagen, General Motors, Hyundai, Nissan and other companies)

5) a significant decrease in the income of airlines and maritime transport: in the first quarter of 2020 , global airline revenues will fall by $\$ 4-5$ billion due to canceled flights to China and a decrease in passenger traffic by $80 \%$; sea transport lost nearly $\$ 4$ billion in revenue in the first quarter of 2020 and is faced with the need to increase freight rates;

6) significant deterioration in the state of the tourism industry; 7)decrease in the income of the population;

8) reduction of expenses on travel, visiting restaurants and cafes, entertainment events, will lead to a crisis in the hotel and restaurant and tourism business and services;

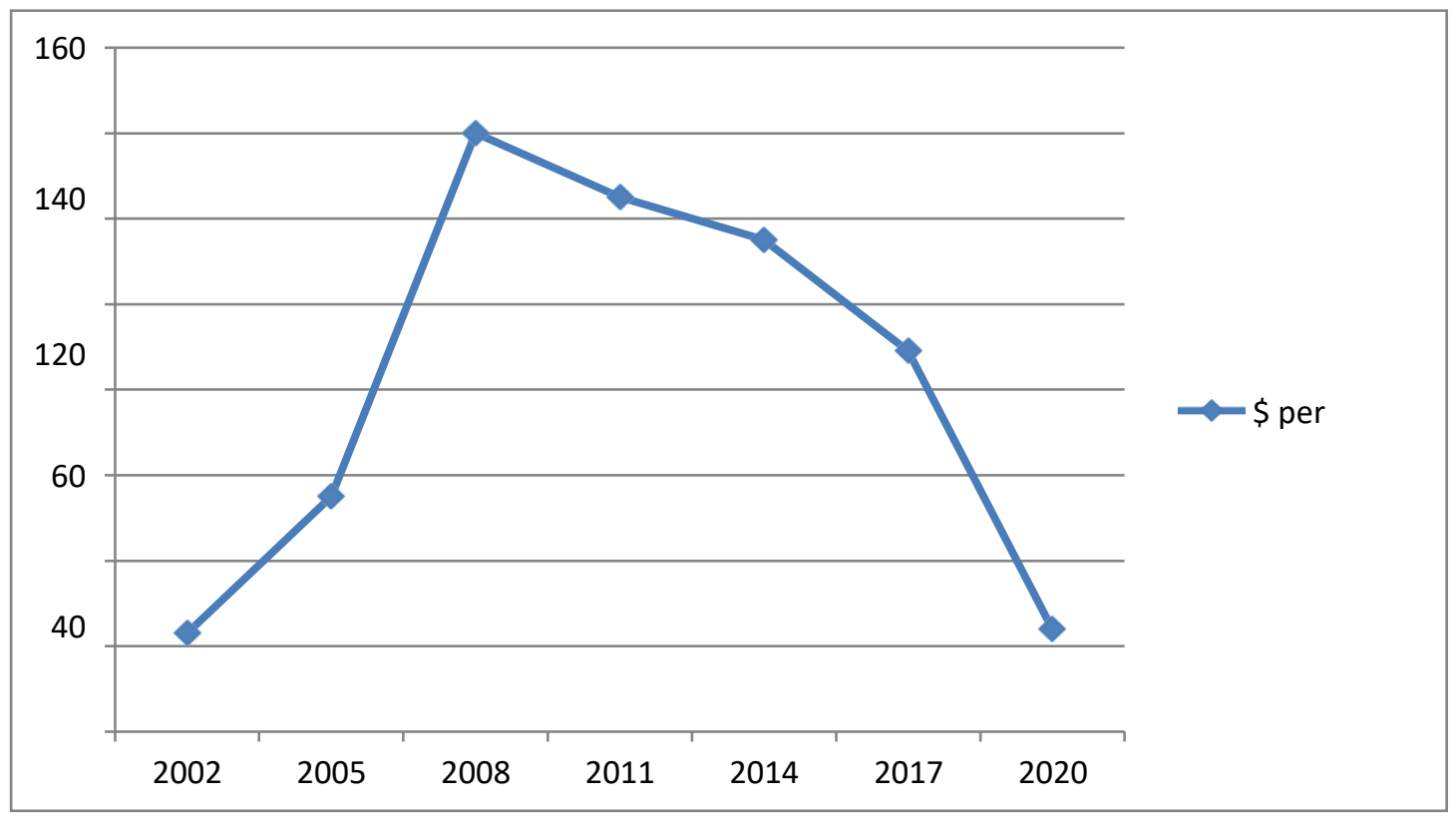

Figure 1. Dynamics of oil prices in 2002-2020 
INTERNATIONAL JOURNAL OF ACADEMIC RESEARCH ECONOMICS AND MANAGEMENT SCIENCES Vol. 10, No. 1, 2021, E-ISSN: 2226-3624 ㄷ 2021 HRMARS

Source: development by authors

9) an increase in the production and sale of pharmaceutical products, in particular medical equipment;

10) growth of more than $\$ 150$ billion in the profits of the global industry of gaming, educational and other online applications;

11) growth in investor demand for less risky assets - government securities and gold;

12) reduction of nitrogen dioxide emissions by more than $36 \%$ compared to the same period in 2019.

In order to prevent the bankruptcy of many small and medium-sized enterprises in China, the People's Bank of China has already injected almost $\$ 174$ billion into the country's financial system. It plans to provide more than $\$ 20$ billion and $\$ 40$ billion in refinancing to Chinese banks for loans to enterprises, most suffer losses from the coronavirus.

At the same time, the International Monetary Fund at the end of March 2020 mobilized \$ 1 trillion to help countries that have suffered financial and economic losses from the spread of the coronavirus pandemic 80 countries have already turned to the IMF for help.

\section{Results and Discussion}

For a better detailing of the crisis caused by the pandemic situation due to the existence of the Covid19 virus, we more scrupulously looked at these consequences using the example of such a country as Ukraine. We are also of the opinion that the crisis that the world will go through as a result of the spread of COVID-19 is global and will hit all countries with open market economies. This will especially shake the financial and economic state of Ukraine, whose economy in recent years has been unstable and dependent on world trends, political eventsand the mood of the population. Even under the optimistic scenario, the fall of the Ukrainian economy due to the spread of COVID-19 in 2020 will amount to 5\% of GDP.

If quarantine ended on November, 2020 (initial forecast), the Ukrainian economy would lose about UAH 16 billion, and budget losses would amount to almost UAH 5 billion. Provided further state financing of budget expenditures would have led to a decrease in GDP by $0.4 \%$, which is generally not critical for the Ukrainian economy. But despite the optimistic forecasts, quarantine continues due to the exacerbation of the coronavirus in Ukraine. Given this situation, consider the vision of the European Business Association, which, referring to Dragon Capital, is considering two forecasts for the development of the Ukrainian economy:

1. Quarantine measures will last until November: a drop in GDP by $4 \%$ and a devaluation of the hryvnia to UAH 30 / \$ (at the end of the year, the average rate is expected to be at UAH 29 (\$), that is, the devaluation will be about $11 \%$ to last year's rate).

2. The quarantine will be extended for a longer period: GDP may fall by $9 \%$, and the hryvnia will fall in price to UAH 35 / \$, unemployment will increase.

Based on these data, we analyzed the losses of the Ukrainian economy from quarantine under the conditions of two scenarios (Table 1) 
Table 1 Forecasts for the losses of the Ukrainian economy in the course of two quarantine scenarios in the context of economic management

\begin{tabular}{|c|c|c|}
\hline Forecast & $\begin{array}{l}\text { Scenario } 1 \\
\text { "baseline" } \\
\text { (quarantine: } \\
\text { October- } \\
\text { December) }\end{array}$ & $\begin{array}{l}\text { Scenario } 2 \\
\text { "moderately } \\
\text { pessimistic" } \\
\text { (quarantine: January-March) }\end{array}$ \\
\hline Falling official employment & $\begin{array}{l}860,000 \text { people - in just } \\
\text { the quarter; } \\
14,000 \text { people per day } \\
\text { of quarantine } \\
\text { (In terms of } \\
\text { quarantine duration } \\
60 \text { days) }\end{array}$ & $\begin{array}{l}\text { In the first quarter of } \\
2020: 862 \text { thousand } \\
\text { people - just for the } \\
\text { quarter; } \\
14 \text { thousand people - for } \\
\text { the day of quarantine. }\end{array}$ \\
\hline Falling real GDP & $\begin{array}{l}\text { In the quarter of } 2020 \text { : } \\
862 \text { thousand people - just } \\
\text { for the quarter; } \\
14 \text { thousand people - for } \\
\text { the day of quarantine. }\end{array}$ & $\begin{array}{l}14.6 \% \text { - for the first quarter } \\
\text { of } 2021 \text {; }\end{array}$ \\
\hline $\begin{array}{l}\text { Budget losses based on } \\
\text { the decline in } \\
\text { employment }\end{array}$ & $\begin{array}{l}\text { for October at the level of } \\
\text { UAH 1.5-2 billion (instead } \\
\text { of }\end{array}$ & $\begin{array}{l}\text { in January-March at the } \\
\text { level of 5-7 billion UAH per } \\
\text { month }\end{array}$ \\
\hline $\begin{array}{l}\text { (estimated by the unified } \\
\text { social contribution and } \\
\text { personal income tax) }\end{array}$ & $\begin{array}{l}\text { UAH } 23-24 \text { billion per } \\
\text { month, SDR-PD FD fees are } \\
\text { expected to amount to UAH } \\
21.5-22 \text { billion. Losses in } \\
\text { December during the } \\
\text { extension of quarantine will } \\
\text { amount to UAH } \\
3-4 \text { billion). }\end{array}$ & \\
\hline $\begin{array}{l}\text { The average annual exchange } \\
\text { rate of hryvnia against } \\
\text { the dollar }\end{array}$ & $30 \mathrm{UAH}$ & $32 \mathrm{UAH}$ \\
\hline
\end{tabular}

Source: development by authors

Added to this is the need to pay off debts on obligations (loans). If we take into account the State budget, then almost UAH 450 billion from the trillion dollar budget is spent on servicing debts.

At the same time, significant losses are incurred by the corporate sector: this will be either a significant decrease in the economic potential of enterprises, primarily human. due to the dismissal of workers or their sending on unpaid leave, or the "extinction" of enterprises.

At the same time, we believe that the deferred (unsatisfied) consumer demand in the future will give the national economy an impetus and the possibility of a quick recovery after a long pause. 
The Ukrainian economy is dependent on the demand for export products, which is falling in the context of the global crisis. This, in turn, leads to a shortfall in the required volume of foreign exchange, a reduction in jobs, and, consequently, a complete slowdown of the economy. In the context of the further spread of COVID-19 in Ukraine, as in the world as a whole, there will be a slowdown in construction volumes, a reduction in road repairs, and the like.

According to experts, it is positive that the demand for agricultural products (which accounts for $40 \%$ of Ukraine's exports) will not decrease, nor are prices expected to fall. At the same time, individual countries may restrict the import of products of foreign origin in order to prevent the spread of the virus.

At the same time, in the near future, Ukraine's chances of successfully placing Eurobonds will significantly decrease, the inflow of foreign investments into hryvnia securities will decrease, and the mood on the foreign exchange market will radically change. All this will significantly increase the pressure on the hryvnia. In these circumstances, with the aim of refinancing the current debt and financing the state budget deficit for Ukraine, the issue of continuing cooperation with international financial institutions, the main of which is the IMF, is relevant and critically important.

Studying the experience of the People's Bank of China, the Ministry of Economic Development, Trade and Agriculture is preparing measures to quickly overcome the possible negative consequences of the coronavirus pandemic for the Ukrainian economy. To do this, the government is revising the state budget and begins to form a stabilization fund for the country, and negotiations are underway with the IMF to attract additional assistance to Ukraine to overcome the coronavirus and support the national economy. At the same time, Ukraine needs fulfill two conditions of the IMF: 1) pass a law on the impossibility of returning banks (nationalized or liquidated) to their former owners; 2) the law on the land market.

Since the main burden of spending on the fight against the pandemic, by decision of the Government of Ukraine, was transferred to local budgets and business structures, it is local communities and representatives of small and medium-sized businesses that in the long run will feel all the negative manifestations of the economic crisis. So, according to the calculations of the All-Ukrainian Association of Local Self-Government Bodies "Association of Ukrainian Cities" from the coronavirus and the measures taken in Ukraine in connection with its spread, local budgets will lose UAH 15.6 billion.

The Atlantic Council experts have prepared a set of principles that will help the Ukrainian economy get back on its feet after the corona of the virus, in particular:

1. Promote the growth of small and medium-sized businesses.

2. Contribute to the development of civil society.

3. Create favorable conditions for foreigners: both for business and for tourism.

\section{Conclusion}

The results of the study suggest that the economic crisis triggered by the COVID-19 pandemic has affected the entire global economy in the context of economic management. Each country will directly or indirectly feel the negative impact of the coronavirus on its financial and economic system and at the and the system of public administration. Depending on the duration of the course of the coronavirus, world experts and politicians are considering several scenarios 
for the development of the global crisis: 1) in the elimination of outbreaks of coronavirus by the second quarter of 2020: global GDP growth will occur at the level of $2 \%$ (instead of 2.5\%);

2) if the coronavirus pandemic cannot be overcome during the first half of 2020: global economic growth will not exceed 1.5\%; 3) in the event of a prolonged COVID-19 pandemic and an increase in the disease during the II-III quarters of 2020: a drop in global GDP by $1.5 \%$. For Ukraine, two scenarios for the development of the national economy have also been proposed, which in one way or another indicate a drop in a number of socio-economic indicators. However, given the uncertainty associated with the development of events around the coronavirus, specific numbers are difficult to predict both for the global economy as a whole and in the context of the economies of individual countries of the world. All this requires informed decisions of the government and local authorities in cooperation with leading experts, the corporate sector and the public in the context of economic management.

\section{References}

Adejare, A., Olla, J., Oluwafemi, J. (2014). Towards A Theoretical Definition of Public Administration. Journal of Management 2319-7668. $16 . \quad 65-$

70.

Barberis, P. (2012) Thinking about the state, talking bureaucracy, teaching public administration. Teaching Public Administration 30(2): 76-91.

Borra's, S. (2011) Policy learning and organizational capacities in innovation policies. Science and Public Policy 38(9): 725-734.

Bovaird, T. (2007). Beyond engagement and participation: User and community coproduction of public services. Public administration review, 67(5), 846-860. https://doi.org/10.1111/j.1540-6210.2007.00773.x

Bovaird, T., and Loeffler, E. (2018) From participation to co-production. In: Ongaro E and van Thiel S (eds) The Palgrave Handbook of Public Administration and Management in Europe. London: Palgrave, pp. 403-424

Bryson, J. M., Quick, K. S., Slotter back, C. S., \& Crosby, B. C. (2013). Designing public participation processes. Public Administration Review, 73(1), 23-24. https://doi.org/10.1111/j.1540-6210.2012.02678.x

Capano, G., and Howlett, M. (2020) The knowns and unknowns of policy instrument analysis: Policy tools and the current research agenda on policy mixes. SAGE Open. https://doi.org/10.1177/2158244019900568

Cooper, T., Bryer, T., \& Meek, J. (2006). Citizen-centered collaborative public management. Public Administration Review, 66, 76-88.

Diamond J., Dunlop C., Elliott I., Farrell C., Ongaro E. (2020) Government versus the virus. 15 May 2020. Available at: https://www.youtube.com/watch?v=ecqLvSIno-Y

Drechsler, W. (2013) Three paradigms of governance and administration: Chinese, Western and Islamic. Society and Economy 35(3): 319-342.

Dunlop, C., Ongaro, E., Baker, K. (2020). Researching COVID-19: A research agenda for public policy and administration scholars. Public Policy and Administration. 35. 365-383. https://doi.org/10.1177/0952076720939631 
Fredrickson, G. (2007) Whatever happened to public administration? Governance, governance everywhere. In: Ferlie, E., Lynn, Jr, L. and Pollitt, C. (eds) The Oxford Handbook of Public Management. Oxford: Oxford University Press, pp. 284-304.

Hafer, J., Ran, B. (2016). Developing a Citizen Perspective of Public Participation: Identity Construction as Citizen Motivation to Participate. Administrative Theory \& Praxis. 38. 206- 222. https://doi.org/10.1080/10841806.2016.1202080

Howlett, M., Mukherjee, I., and Woo, J. (2015) The new design orientation in policy formulation research: From tools to toolkits in policy instrument studies. Policy and Politics43(2): 291-311.

Khan, A. M., Ullah, M., Usman, A., Malik, A. H., Khan, K. M. (2020). Impact of Covid-19 on Global Economy. International Journal of Management, 11(8), 2020, pp. 956-969

McSwite, O. (2005). Taking public administration seriously: Beyond humanism and bureaucrat bashing. Administration \& Society, 37(1), 116-125. https://doi.org/10.1177/0095399704272402

Ongaro, E., and Van Thiel, S. (2018) Languages and public administration in Europe. The Palgrave Handbook of Public Administration and Management in Europe. London: Palgrave, pp. 61-98.

Prystupa, Ye., Kryshtanovych, S., Danylevych, M., Lapychak, I., Kryshtanovych, M., Sikorskyi, P., Podolyak, Z., Basarab, V. (2020) Features of formation the professional competence of future managers of physical culture and sports. Journal of Physical Education and Sport (JPES), pp 441-446. Vol. 20

Piattoni, S. (2009) Multi-level governance: A historical and conceptual analysis. Journal of European Integration 31(2): 163-180.

Porter, S., and Hook, D. (2020). How COVID-19 is Changing Research Culture. London:Digital Science.

Randma-Liiv, T., Kickert, W. (2018) The impact of the fiscal crisis on public admin-is tration in Europe. The Palgrave Handbook of Public Administration and Management in Europe. London: Palgrave, pp. 899-917.

Rowe, G., \& Frewer, L. J. (2004). Evaluating public-participation exercises: A research agenda. Science, Technology, \& Human Values, 29(4), 512-556. https://doi.org/10.1177/0162243903259197

Spanou, C. (2020) External influence on structural reform: Did policy conditionality strength-en reform capacity in Greece? Public Policy and Administration 35(2): 135-157.

Talbot C. (2018) Usable knowledge: Discipline-oriented versus problem-oriented social science in public policy. In: Ongaro E and van Thiel S (eds) The Palgrave Handbook of Public Administration and Management in Europe. London: Palgrave, pp. 1213-1234

Ullah, M., Khan, A. M., Usman, A. (2020). COVID-19 and Global Stock Market. International Journal of Management. 12(2), 374-380. 